\title{
Perubahan Kandungan Nutrisi dan Kecernaan in vitro Serbuk Gergaji Hasil Biokonversi Menggunakan Inokulum Jamur Tiram Putih (Pleurotus ostreatus) dengan Level Suplementasi Urea yang Berbeda
}

\author{
Nutrient Content Differences and in vitro Digestibility of Shaw Dust as the Yield of \\ Bioconversion Using White Rod Fungi (Pleurotus ostreatus) Supplemented with Different \\ Levels of Urea \\ R. Krishaditersanto ${ }^{1}$, T.O.D. Dato ${ }^{2,}$ dan A.E. Manu ${ }^{2}$ \\ ${ }^{1}$ Post Graduate Program of Animal Husbandry, Nusa Cendana University, Kupang \\ ${ }^{2}$ Animal Husbandry Faculty, Nusacendana University, Kupang \\ Email : ripk78@gmail.com
}

\begin{abstract}
This study aims to determine the effect of urea supplementation on substrate on changes in nutrients and digestibility in vitro of sawdust which was bioconversion using Pleurotus ostreatus with 40 days incubation period. The design used was single factor Completely Randomized Design (CRD) with 4 levels of urea supplementation and 3 replications. Observed parameters were percentage change of dry matter, organic matter, crude fiber, crude protein, and fat; and altered digestibility in vitro dry matter as well as organic matter. Data analysis using analysis of variance, showed that urea supplementation had significant effect $(\mathrm{P}<0.05)$ on the percentage of decrease of dry matter, organic matter, and crude fiber where the highest decrease percentage at the level of $1 \%$ urea supplementation. The percentage increase of crude protein and crude fat content was significantly different $(\mathrm{P}<0.05)$ in each treatment, the highest percentage increase at the level of $1 \%$ urea supplementation. Urea supplementation also significantly influence $(\mathrm{P}<0.05)$ on the percentage increase of in vitro digestibility of dry matter and organic matter where the highest increase was at the level of $1 \%$ urea supplementation in the substrate.
\end{abstract}

Key words: Pleurotus ostreatus, sawdust, urea

\begin{abstract}
ABSTRAK
Penelitian ini bertujuan untuk mengetahui pengaruh suplementasi urea pada subtrat terhadap perubahan kandungan nutrisi dan kecernaaan in vitro serbuk gergaji hasil biokonversi menggunakan inokulum jamur tiram putih (Pleurotus ostreatus) dengan lama inkubasi 40 hari. Rancangan yang digunakan adalah Rancangan Acak Lengkap (RAL) faktor tunggal dengan 4 level suplementasi urea dan 3 ulangan. Paramenter yang diamati adalah persentase perubahan kandungan bahan kering, bahan organik, serat kasar, protein kasar, serta lemak kasar; dan perubahan kecernaan in vitro bahan kering serta bahan organik. Analisa data menggunakan analisi variansi menunjukan bahwa suplementasi urea berpengaruh nyata $(\mathrm{P}<0,05)$ terhadap persentase penurunan bahan kering, bahan organik, dan serat kasar dimana persentase penurunan terrtinggi pada suplementasi urea sebanyak $1 \%$. Persentase peningkatan kandungan protein kasar dan lemak kasar secara nyata berbeda $(\mathrm{P}<0,05)$ pada tiap perlakuan, persentase peningkatan teringgi pada level suplementasi urea $1 \%$. Suplementasi urea juga berpengaruh secara nyata $(\mathrm{P}<0,05)$ terhadap persentase peningkatan kecernaan in vitro bahan kering dan bahan organik dimana peningkatan paling tinggi pada level suplementasi urea $1 \%$ dalam subtrat.
\end{abstract}

Kata kunci: jamur tiram putih, serbuk gergaji, urea

\section{PENDAHULUAN}

Pada usaha peternakan biaya untuk mengadakan pakan merupakan biaya terbesar dibandingkan faktor lain, demikian pula dengan peternakan sapi. Sebagai ternak ruminansia sapi dapat memanfaatkan pakan berserat yang berasal dari ikutan produk pertanian maupun perkebunan. Salah satu produk ikutan tersebut adalah serbuk gergaji yaitu produk samping dari pengolahan kayu. Serbuk 
gergaji merupakan biomasa berlignoselusolsa dengan kandungan 79,9\% bahan kering, dengan kandungan serat kasar mencapai $53,3 \%$, dan protein kasar 4,63\% (Ibrahim, 2013). Dari komposisi tersebut serbuk gergaji memiliki potensi menjadi sumber pakan ruminansia, seperti produk samping pertanian yang lain dimana kandungan nutrisi dan kecernaan yang rendah maka serbuk gergaji perlu perlakuan terlebih dahulu sebelum dijadikan pakan.

Perlakuan untuk memperbaiki nutrisi serbuk gergaji baik secara kimia dengan asam maupun basa kuat, bahkan menggunakan sinar gamma $(\gamma)$ seperti yang dilakukan oleh Lawton et al. (1951). Penggunaan bahan kimia meninggalakan limbah yang harus ditangani dengan hatihati, sehingga perlakuan secara biologi (biokonversi) menjadi pilihan yang lebih baik. Salah satunya adalah biokonversi dengan memanfaatkanjamur tiram putih (Pleurotus ostreatus, jamur ini termasuk jamur pelapuk putih yang menghasilkan enzim Manganese peroksida (MnP) dan Lignin Peroksida (LiP) yang merupakan enzim ektraseluler yang efektif mendegradasi lignin (Widiastuti dan Panji. 2008). Dalam pertumbuhannya jamur tiram putih membutuhkan unsur nitrogen (N) (Yuliastuti dan Susilo, 2003) sedangkan kandungan $\mathrm{N}$ pada serbuk gergaji rendah, oleh karena itu suplementsi urea sebagai sumber $\mathrm{N}$ dilakukan untuk pengetahui perubahan kualitas nutrisi serbuk gergaji hasil biokonversi.

\section{MATERI DAN METODE}

Rancangan percobaan pada penelitian ini adalah rancangan acak lengkap dengan 5 perlakuan dan 3 ulangan sehingga diperoleh 15 unit percobaan. Kelima perlakuan tersebut adalah: P0 subtrat $+0 \%$ urea; P1 subtrat $+0,5 \%$ urea; P2 sumbtrat $+1 \%$ urea; P3 subtrat + $1,5 \%$ urea; dan $\mathrm{P} 4$ subtrat $+2 \%$ urea.

Materi dalam penelitian ini adalah serbuk gergaji dari penggergajian kayu di kota kupang dan bahan additif yang terdiri dari $10 \%$ dedak; $1,5 \% \mathrm{CaSO}_{4} .2 \mathrm{H}_{2} \mathrm{O} ; 0,5 \%$ $\mathrm{CaCO}_{3}$; dan air. Bahan-bahan tersebut dicampur hingga homogen dan ditambah air kurang lebih $70 \%$ yang ditandai ketika dikepal menggumpal tapi air tidak menetes. Campuran ini selanjutnya disebut subtrat awal.

Selanjutanya pada subtrat awal ditambahkan urea sesuai perlakuan, kemudian dimasukan dalam kantong plastik polipropilen ukuran diameter $18 \mathrm{~cm}$ ketebalan $0,5 \mathrm{~cm}$ lalu dipadatkan hingga tinggi $20 \mathrm{~cm}$, selanjutnya ujung plastik disatukan dan dipasang cincin yang terbuat dari pipa pralon 0,5 inch, lobang cincin ditutup dengan kapas dan selanjutnya dilakukan sterilisasi selama 2 jam pada suhu $121{ }^{\circ} \mathrm{C}$ dengan tekanan 1 atm (Kerem et al., 1992), kemudian didinginkan selama 12 jam. Subtrat diinokulasi dengan inokulum jamur tiram putih berumur 5-6 minggu dengan dosis $25 \mathrm{~g} / \mathrm{kg}$ sebagai dosis terbaik (Ghunu, 1998). Setelah diinokulasi baglog disusun di rak dalam ruang 
inkubasi selama 40 hari, setelah itu masing masing baglog dibuka lalu dicampur hingga homogen. Setelah itu sampel dikeringkan menggunakan oven selama 48 jam pada suhu $60^{\circ} \mathrm{C}$, lalu digiling untuk analisis kandungan nutrisi dan kecernaan in vitro.

Parameter yang diamati meliputi persentase perubahan: 1) kandungan nutrisi meliputi Bahan Kering [BK], Bahan Organik [BO], Protein Kasar [PK], Lemak Kasar [LK], dan Serat Kasar [SK]; 2) persentase perubahan kecernaan in vitro meliputi perubahan Kecernaan Bahan Kering $[\mathrm{KcBK}]$, dan Kecernaan Bahaan Organik [KcBO]. Penghitungan persentase perubahan kandungan nutrisi sebagai berikut :

Perubahan Kandungan Nutrisi $(\%)=$

Nutrisi Hasil Biokonversi - Nutrisi Awal

Nutrisi Awal
Untuk mengetahui respon perlakuan terhadap kandungan nutrisi data yang terkumpul dianalisis dengan One Way Analysis of Variance (Anova), apabila $F_{\text {hitung }}$ nyata atau sangat nyata, dilanjutkan dengan Uji Jarak Berganda Duncan (Duncan Multiple Range Test [DMRT]).

\section{HASIL DAN PEMBAHASAN}

\section{Persentase Perubahan Kandungan Nutrisi \\ Rataan persentse perubahan} kandungan nutrisi serbuk gergaji hasil biokonversi menggunakan inokulum jamur tiram putih disajikan pada tabel 1. Hasil analisis statistik menunjukan suplementasi urea memberikan pengaruh nyata $(\mathrm{P}<0,05)$ terhadap persentase penurunan BK, BO, dan SK. Suplementsi urea juga memberikan pengaruh nyata $(\mathrm{P}<0,05)$ terhadap peningkatan kandungan $\mathrm{PK}$ dan LK serbuk gergaji hasil biokonversi.

Tabel 1. Rataan persentase perubahan nutrisi serbuk gergaji hasil biokonversi

\begin{tabular}{cccccc}
\hline Perlakuan & $\begin{array}{c}\text { Penurunan } \\
\text { BK }(\%)\end{array}$ & $\begin{array}{c}\text { Penurunan } \\
\text { BO }(\%)\end{array}$ & $\begin{array}{c}\text { Penurunan } \\
\text { SK }(\%)\end{array}$ & $\begin{array}{c}\text { Peningkatan } \\
\text { PK }(\%)\end{array}$ & $\begin{array}{c}\text { Peningkatan } \\
\text { LK }(\%)\end{array}$ \\
\hline P0 & $1,14^{\mathrm{a}}$ & $1,10^{\mathrm{a}}$ & $7,15^{\mathrm{a}}$ & $5,04^{\mathrm{a}}$ & $73,06^{\mathrm{a}}$ \\
$\mathrm{P} 1$ & $1,58^{\mathrm{b}}$ & $1,54^{\mathrm{b}}$ & $9,96^{\mathrm{b}}$ & $25,62^{\mathrm{b}}$ & $98,64^{\mathrm{b}}$ \\
$\mathrm{P} 2$ & $2,09^{\mathrm{c}}$ & $2,03^{\mathrm{c}}$ & $13,23^{\mathrm{c}}$ & $33,66^{\mathrm{c}}$ & $140,72^{\mathrm{c}}$ \\
$\mathrm{P} 3$ & $1,63^{\mathrm{d}}$ & $1,49^{\mathrm{b}}$ & $11,92^{\mathrm{d}}$ & $33,09^{\mathrm{c}}$ & $122,67^{\mathrm{d}}$ \\
P4 & $1,20^{\mathrm{a}}$ & $1,39^{\mathrm{b}}$ & $7,85^{\mathrm{e}}$ & $25,48^{\mathrm{b}}$ & $89,68^{\mathrm{b}}$ \\
\hline Rataan & 1,53 & 1,51 & 10,0 & 24,58 & 104,96 \\
Total & & & & \\
\hline \multicolumn{7}{r}{ Keterangan: superskrip yang berbeda pada kolom yang sama menunjukan perbedaan nyata $(P<0,05)}$.
\end{tabular}

Persentase Penurunan Kandungan Bahan Kering (BK), Bahan Organik (BO), dan Serat Kasar (SK)

Suplementasi urea menyebabkan penurunan kandungan $\mathrm{BK}$, BO, dan SK serbuk gergaji hasil biokonversi pada semua perlakuan. Penurunan kandungan BK dan BO ini terjadi karena jamur tiram putih merombak komponen dalam serbuk gergaji menjadi produk yang larut dalam air dan $\mathrm{CO}_{2}$ (Boyle et al., 1992). 
Suplementasi urea hingga $1 \% \quad(\mathrm{P} 2)$ memberikan persentaase penurunan $\mathrm{BK}$ yang paling tinggi yaitu menurun sebesar 2,09\%, demikian pula persentase penurunan kandungan $\mathrm{BO}$ yang tertinggi adalah pada suplementasi $1 \% \quad(\mathrm{P} 2)$. Suplementasi urea hingga $1 \% \quad$ (P2) menyebabkan penurunan kandungan SK paling tinggi sebesar 13,23\%, penurunan serat SK diakibatkan miselium jamur tiram putih menghasilkan enzim yang mendegradasi komponen serat (selulosa, hemiselulosa, dan lignin) jamur tiram putih sebagai jamur pelapuk putih mengahasilkan enzim selulase yang akan mendegradasi selulosa menjadi lebih sederhana (Wood et al., 1988). Pada jamur pelapuk putih (termasuk jamur tiram putih) juga mengahsilkan enzim pendegradasi lignin yaitu Lignin Peroksidase (Reid, 1994 ; Chang dan Bumpus, 2001).
Persentase penurunan $\mathrm{BK}, \mathrm{BO}$, dan SK meningkat dari P0, P1 hingga mencapai puncaknya pada P2 lalu mulai menurun pada P3 dan P4, hal ini diduga akibat pertumbuhan miselium jamur tiram putih dengan adanya penambahan urea hingga $1 \%$ akan tetapi pada penambahan lebih dari $1,5 \%$ justru akan menghambat pertumbuhannya. Pola penurunan kandungan BK, BO, dan SK tergambar pada Gambar 1. Menurut Yuliastuti dan Susilo (2003), jamur menggunakan nitrogen terutama dalam bentuk amonium sebagai pemasok $\mathrm{N}$ untuk pertumbuhannya, akan tetapi jumlah amonium bebas yang berlebih akan bersifat toksik sehingga menghambat pertumbuhan jamur tersebut. Dalam subtrat urea akan terurai dan membentuk amonium hidroksida $\left(\mathrm{NH}_{4} \mathrm{OH}\right)$ sebagai sumber $\mathrm{N}$ bagi pertumbuhan jamur tiram putih.

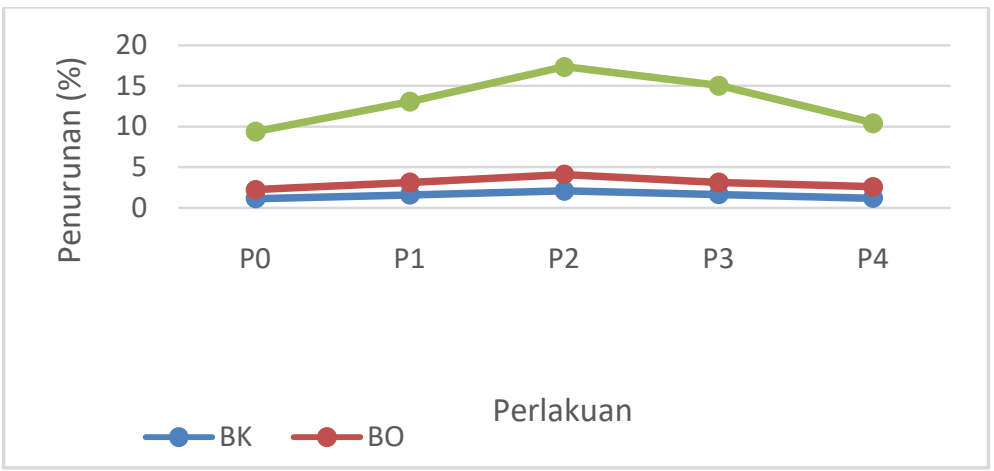

Gambar 1. Persentase penurunan kandungan bahan kering, bahan organik, dan serat kasar

Suplementasi urea hingga $1 \%$ yaitu pada P2 menyebabkan pertumbuhan miselium jamur tiram putih yang lebih banyakakan tetapi pada penambahan $1,5 \%$ yaitu P3 dan 2\% yaitu pada P4 akan menghambat pertumbuhan miselium jamur tiram putih. Miselium ini terdiri dari kumpulan hifa yang memproduksi enzimenzim. Penelitian Kassim et al., (1985) melaporkan bahwa terdapat hubungan yang positif antara pertumbuhan miselium dan produksi enzim. Pertumbuhan miselium yang lebih banyak pada P2 maka produksi enzim akan lebih banyak pula 
pada $\mathrm{P} 2$, hal ini menyebabkan persentse penurunan $\mathrm{BK}, \mathrm{BO}$, dan SK paling besar dibanding perlakuan lain.

\section{Peningkatan Kandungan Protein Kasar (PK) dan Lemak Kasar (LK)}

Suplementasi urea pada level $1 \%$

(P2) memberikan persentase peningkatan

PK yang terbaik yaitu 33,66\% dibandingkan perlakuan lain, meskipun tidak berbeda dengan P3 sebesar 33,09\%. Persentase peningkatan kandungan PK meningkat dari P0, P1, dan pada P2 persentase peningkatan yang paling tinggi. Persentase peningkatan PK mulai menurun pada P3 dan terus menurun pada P4. Pola peningkatkan kandungan PK tergambar pada Gambar 2. Kondisi ini sejalan dengan penelitian Noferdiman et al. (2008) yang menunjukan peningkatan pertumbuhan jamur Phanerochaete chrysosporium dengan penambahan urea hingga $1,5 \%$ dan mulai menurun pada penambahan urea $2 \%$ pada subtrat lumpur sawit yang ditandai dengan penurunan jumlah spora yang dihasilkan jamur tersebut. Pada penelitian lain, Trahaju (1994), dilaporkan bahwa penambahan nitrogen anorganik (urea) 0,5-1,5\% dalam subtrat serbuk gergaji mampu memberikan pertumbuhan jamur Marasimus Sp cukup tinggi. Menurut Garraway dan Evans (1984), jamur membutuhkan karbon dan nitrogen untuk pembentukan sel tubuhnya, sehingga semakin banyak pertumbuhan miselium juga akan makin banyak nitrogen tubuh. Kandungan protein pada membran sel pada jamur berhifa adalah 25-45\%, dengan kandungan karbohidrat 25-35\%, sedangkan pada dinding selnya mengandung protein 6,3\% (Fardias dan Winarno, 1980). Seiring dengaan pertumbuhan miselium yang lebih baik pada P2 maka persentase peningkatan kandungan protein juga lebih tinggi. Dengan pertumbuhan miselium yang lebih banyak maka enzim yang dihasilkan juga meningkat (Kassim et al., 1985), dan enzim ini juga merupakan protein.

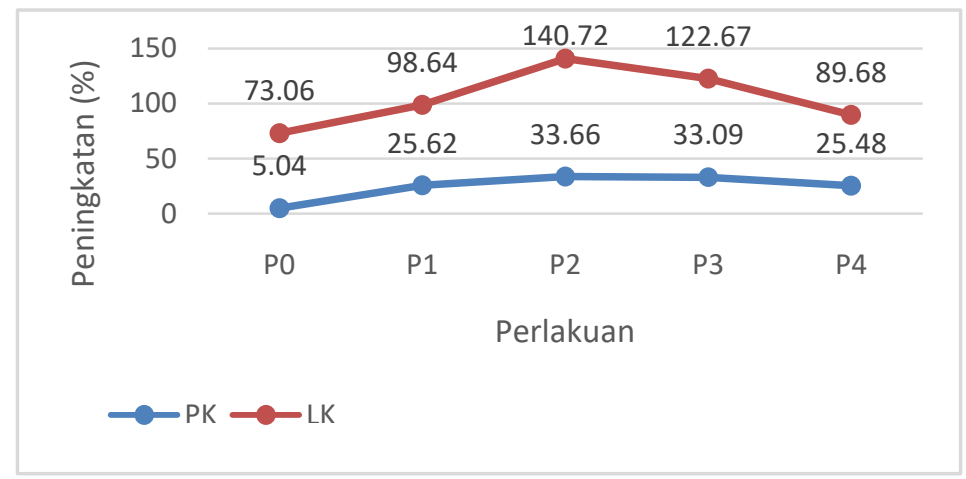

Gambar 2. Persentase penigkatan PK dan LK

Suplementasi urea pada subtrat pemberikan pengaruh nyata $(\mathrm{P}<0,05)$ terhadap persentase penigkatan kandungan LK. Dari Gambar 2, tergambar bahwa persentae peningkatan LK meningkat dari
P0, P1, hingga pada P2 mencapai puncaknya sebesar $140,72 \%$, lalu mulai menurun pada P3 hingga P4. Peningkatan 
baik pada $\mathrm{P} 2$ sebagai akibat suplementasi urea dan menurun pada P3 dan P4 karena suplementasi urea menyebabkan jumlah amonium bebas dalam subtrat berlebih yang akan menghambat pertumbuhan jamur (Yuliastuti dan Susilo. 2003).

Kandungn LK ini bersasal dari pembentukan miselium jamur. Kandungan lemak jamur tiram putih mencapai 2,56$5,86 \%$ dari bahan keringnya (Patil et al., 2010), sehingga semakin banyak miselium terbentuk semakin besar pula persentase peningkatan kandungan lemak dalam subtrat serbuk gergaji hasil biokonversi. Jamur menggunakan nitrogen dalam untuk sintesis protein, purin dan pirimidin. Selain itu bagi jamur nitrogen juga diperlukan untuk pembentukan lemak dan senyawa organik lain (Kalsum et al., 2011).

\section{Persentase Peningkatan Kecernaan in vitro}

Kecernaan in vitro $\mathrm{BK}(\mathrm{KcBK})$ dan kecernaan $\mathrm{BO}(\mathrm{KcBO})$ serbuk gergaji hasil biokonversi menunjukan adanya peningkatan pada semua perlakuan dibandingkan sebelum biokonversi. Suplementasi urea pada subtrat memberikan pengaruh nyata $(\mathrm{P}<0,05)$ terhadap persentase perubahan kecernaan serbuk gergaji hasil biokonversi, terlihat pada tabel 2.

Tabel 2. Persentase peningkatan kecernaan in vitro bahan kering dan bahan organik

\begin{tabular}{lll}
\hline Perlakuan & Peningkatan KcBK $(\%)$ & Peningkatan KcBO \\
\hline P0 & $22,25^{\mathrm{a}}$ & $25,90^{\mathrm{a}}$ \\
P1 & $31,75^{\mathrm{b}}$ & $49,22^{\mathrm{b}}$ \\
P2 & $47,94^{\mathrm{c}}$ & $64,03^{\mathrm{c}}$ \\
P3 & $46,60^{\mathrm{c}}$ & $61,74^{\mathrm{c}}$ \\
P4 & $24,47^{\mathrm{ab}}$ & $29,97^{\mathrm{a}}$ \\
\hline Rataan Total & 34,60 & 60,12 \\
\hline
\end{tabular}

${ }^{\bar{a}-c}$ Superskrip berbeda pada kolom yang sama menunjukan beda nyata $(\mathrm{P}<0,05)$

Kecernaan pakan menunjukan jumlah nutrisi yang dapat dimanfaatkan oleh ternak, sehingga selain dilihat dari kandungaan nutrisinya kualitas pakan juga harus dilihat dari nilai kecernaannya (Tilman et al., 1998). Suplementasi urea menyebabkan persentase peningkatan kecernaan in vitro $\mathrm{BK}$ dan $\mathrm{BO}$ meningkat dari P0, P1 sampai dengan P2, setelah itu mulai menurun pada P3 dan P4. Kecernaan BO meningkat seiring dengan peningkatan KcBK hal ini karena sebagian besar komponen bahan kering adalah bahan organik (Sutardi, 1980) dan ditegaskan oleh Darwis (1990) bahwa kecernaan bahan organik berbanding lurus dengan kecernaan bahan kering.

Pola persentase peningkatan $\mathrm{KcBK}$ dan $\mathrm{KcBO}$ sejalan dengan persentase peningkatan kandungan PK dan LK (Grafik 2), serta persentase penurunan SK (Gambar 1). Pola presentase peningkatan $\mathrm{KcBK}$ dan $\mathrm{KcBO}$ tersebut tergambar pada Gambar 3. Menurut Van Soest (1994), 
kecernaan bahan pakan akan terhambat oleh adanya lignin yang berikatan dengan selulosa dan hemiselulosa. Jamur tiram putih menghasilkan enzim-enzim yang mampu mendegradasi lignin yaitu Lignin Peroksidase (LiP), Manganese Peroksidase $(\mathrm{MnP})$, Lakase dan enzim lain penghasil $\mathrm{H}_{2} \mathrm{O}_{2}$ (Hatakka, 2000). Suplementasi urea hingga $1 \%$ memberikan pertumbuhan jamur yang paling baik sehingga enzim yang dihasilkan lebih banyak. Menurut Kassim et al. (1985), terdapat hubungan yang positif antara pertumbuhan miseliun dan produksi enzim. Hal ini juga terlihat dari persentase penurunan kandungan SK pada $\mathrm{P} 2$ yang paling besar (Tabel 1.) yang diduga akibat aktivitas ezim mendegradasi komponen SK termasuk lignin.

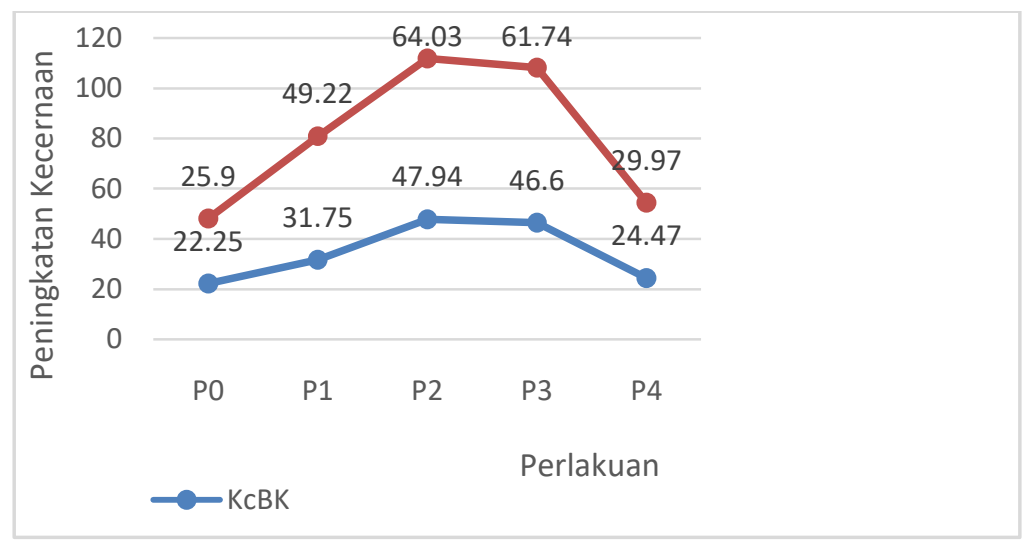

Gambar 3. Persentase Peningkatan KcBK dan KcBO

Degradasi lignin tersebut akan subtrat adalah yang terbaik untuk menyebabkan ikatan lignin dengan meningkatkan kualitas nutrisi dan selulosa dan hemiselulosa menjadi kecernaan serbuk gergaji hasil biokonversi renggang sehingga dapat dimanfaatkan menggunakan inokulum jamur tiram putih. oleh mikroba untuk dicerna. Peningkatan kandungan PK dan LK juga menyebabkan DAFTAR PUSTAKA nilai kecernaan pakan meningkat. Menurut Boorman (1980) bahwa kecernaan protein sangat dipengaruhi oleh kualitas protein dalam pakan. Kualitas protein yang dihasilkan jamur tiram putih lebih baik kualitasnya jika dibanding protein pada serbuk gergaji sebelum biokonversi sehingga dapat dimanfaatkan oleh mikroba.

\section{KESIMPULAN}

Berdasarkan penelitian yang telah dilakukan dapat disimpulkan bahwa suplementasi urea dengan dosis $1 \%$ pada 
Chang, H.C and J.A. Bumbpus. 2001. Inhibition of lignin peroxidase mediated oxidation activity by athylenediamine tetra acetic acid and N-N-N'-N' tetrametylenediamine. Proc. Natl. Sci. Coun. 25 (1) : 26-33.

Darwis, A. 1990. Produsi Enzim Sellulase dan Biomassa untuk Pakan Ternak dan Biokonversi Coklat oleh Thrichoderma viridae. Karya Ilmiah. Fakultas Peternakan Universitas Jambi. Jambi.

Fardias, S dan F.G. Winarno 1980. Pengantar Teknologi Pangan. Penerbit Gramedia, Jakarta.

Garraway, M.D. and R.C. Evans. 1984. Fungal Nutrition and Physiology. John Wiley \& Sons., Singapore.

Ghunu, S. 1998. Efek Dosis Inokulum dan Lama Biokonversi Ampat Tebu sebagai Bahan Pakan oleh Jamur Tiram Putih (Pleurotus ostreatus) terhadap Kandungan Komponen Seraat, Protein Kasar, dan Energi Dapat Dicerna pada Domba. Tesis Pascasarjana, Universitaass Padjadjaran. Bandung.

Hatakka. 2000. Biodegradation of Lignin. University of Helsinki, Viiki Biocenter, Departement of Applied Chemistry and Microbiology. Helsinki.

Ibrahim, Y., El-Ladan, and E. A. Olofin. 2013. Proximate and Mineral
Analyses of Variously Treadted Sawdust as a Potential Livestock Feed. Int. J. Pure Appl. Sci. Technol. 19 (1): 44-48.

Kalsum, U., S. Fatimah., dan C. Wasonowati. 2011. Efetifitas Pemberiaan Air Leri terhadap Pertumbuhan dan Hasil Jamur Tiram Putih (Pleurotus ostreatus). Agrovigor. 4 (2) : 86-92.

Kassim, E.A., I.M. Ghazi, and Z.A. Nagieb. 1985. Effect of Pretreatment of Cellulosic Waste on The Production of Cellulose Enzymes by Trichoderma reesei. J. of Ferment. Technol. 6 (3) :129-193.

Kerem, Z., D. Friesem, and Y. Hadar. 1992. Lignocellulose Degradation during Solid-State Fermentation: Pleurotus ostretus versus Phanerochaete chryssosporium. Apllied and Environmental Microbiology, 58 (4): 1121-1127.

Patil, S.S., S.A. Ahmed., S.M. Telang., and M.M.V Baig. 2010. The Nutritional Value of Pleurotus Ostreatus (JACQFR.) Kumm Cultivated on Different Lignocellulosic Agro-Waste. Innovative Romanian Food Biotechnology. 7 : 66-76.

Reid, I.D. 1985. Biological delignification os aspen wood by solid state fermentation with the white rot fungus Merulius tremelosus, J. 
Appl. Environ. mocrobiol, 50. (1) : 133-139.

Sutardi, T., N. A. Sigit, dan T. Toharmat. 1983. Standarisasi Mutu Protein Bahan Makanan Ruminansia Berdasarkaan Parameter Metabolisme oleh Mikroba Rumen. Fakultas Peternakan IPB. Bogor.

Tillman, A.D., H. Hartadi, S. Reksohadiprojo, S. Prawirokusumo, dan S. L. Soekotjo. 1989. Ilmu Makanan Ternak Dasar. Gadjah Mada University Press, Yogyakarta.
Trahaju. 1994. Pengaruh Urea dan Ampas Tapioka dalam Proses Dekomposisi Serbuk Gergaji Kayu Albasia dan Kayu Kapur oleh Jamur CULH. Tesis Pascasarjana. ITB, Bandung.

Yuliastuti, E., dan A. Susilo. 2003. Studi Kandungan Nutrisi Limbah Media Tanam Jamur Tiram Putih (Pleurotus ostreatus) untuk Pakan Ternak Ruminansia. Jurnal Matematika, Saint, dan Teknologi. 4 (1): 54-61. 